\title{
Biodiversity and the functioning of seagrass ecosystems
}

\author{
J. Emmett Duffy* \\ School of Marine Science and Virginia Institute of Marine Science, The College of William and Mary, Gloucester Point, \\ Virginia 23062-1346, USA
}

\begin{abstract}
Biodiversity at multiple levels - genotypes within species, species within functional groups, habitats within a landscape-enhances productivity, resource use, and stability of seagrass ecosystems. Several themes emerge from a review of the mostly indirect evidence and the few experiments that explicitly manipulated diversity in seagrass systems. First, because many seagrass communities are dominated by 1 or a few plant species, genetic and phenotypic diversity within such foundation species has important influences on ecosystem productivity and stability. Second, in seagrass beds and many other aquatic systems, consumer control is strong, extinction is biased toward large body size and high trophic levels, and thus human impacts are often mediated by interactions of changing 'vertical diversity' (food chain length) with changing 'horizontal diversity' (heterogeneity within trophic levels). Third, the openness of marine systems means that ecosystem structure and processes often depend on interactions among habitats within a landscape (landscape diversity). There is clear evidence from seagrass systems that advection of resources and active movement of consumers among adjacent habitats influence nutrient fluxes, trophic transfer, fishery production, and species diversity. Future investigations of biodiversity effects on processes within seagrass and other aquatic ecosystems would benefit from broadening the concept of biodiversity to encompass the hierarchy of genetic through landscape diversity, focusing on links between diversity and trophic interactions, and on links between regional diversity, local diversity, and ecosystem processes. Maintaining biodiversity and biocomplexity of seagrass and other coastal ecosystems has important conservation and management implications.
\end{abstract}

KEY WORDS: Food web · Habitat structure $\cdot$ Landscape $\cdot$ Production $\cdot$ Stability $\cdot$ Trophic transfer Resale or republication not permitted without written consent of the publisher

\section{INTRODUCTION}

Seagrass beds are among the most widespread and productive coastal ecosystem types worldwide, and range from the tropics to boreal margins of every ocean (Hemminga \& Duarte 2000). Seagrasses provide physical structure on otherwise largely featureless sediment bottoms, enhancing community diversity, biomass, and primary and secondary production. The leaves provide a substratum for growth of epiphytic microalgae that fuel food webs and a shelter for invertebrates and fishes that reach substantially greater densities than in unvegetated benthic habitats (Heck \& Orth 1980, Orth et al. 1984). This combined productivity of seagrasses and associated algae ranks seagrass beds among the most productive ecosystems on earth (Duarte \& Cebrián 1996), and their provision of nursery areas for juvenile stages of commercially important species (Heck et al. 2003) contributes significantly to the economic importance of estuarine fisheries (Anderson 1989, Costanza et al. 1997). Moreover, because much seagrass production ends up in below-ground tissues and ungrazed detritus, seagrass beds are an important global sink for carbon, accounting for an estimated $15 \%$ of net $\mathrm{CO}_{2}$ uptake by marine organisms on a global scale, despite contributing only $1 \%$ of marine primary production (Duarte \& Chiscano 1999).

Unfortunately, seagrass beds are also among the most threatened of marine habitats (Short \& WyllieEchevarria 1996, Duarte 2002). As in most other shallow marine ecosystems, 3 threats stand out as being especially pervasive. These are eutrophication (Howarth et al. 2000, Cloern 2001), overfishing (Jackson et al. 2001), and the destruction of physical and 
biogenic habitat (Watling \& Norse 1998, Thrush \& Dayton 2002). These impacts, along with pollution, have caused major changes in abundance, species composition, and structure of marine communities, including regional and even global extinctions (Carlton et al. 1999, Jackson et al. 2001). Of the several types of human insults that the natural world faces, however, species extinction is arguably unique in being the only one that is irreversible. Thus, there are compelling reasons for understanding how declining biodiversity mediates ecosystem functional processes such as productivity, trophic transfer, and carbon storage.

Recognizing these links, the potential influence of changing biodiversity on ecosystem functioning (BEF) has become a central topic in ecology and conservation biology (Tilman 1999, Loreau et al. 2001, Naeem 2002, Srivastava \& Vellend 2005) and a controversial one (Huston 1994, Huston et al. 2000, Schwartz et al. 2000, Wardle et al. 2000). By ecosystem functioning, I mean aggregate processes of whole ecosystems, such as primary and secondary production, trophic transfer, biogeochemical fluxes, and resistance and resilience of ecosystem-level properties to disturbance. In this review, I consider whether and how changing biodiversity, across a hierarchy of taxonomic and ecological scales, may influence the functioning of seagrass ecosystems, based on the few explicit experimental tests of such relationships and on inferences from other lines of evidence. I close with thoughts on how this research might inform our response to mitigating worldwide seagrass decline and its consequences for ecosystem services important to human society.

\section{FUNCTIONAL ASPECTS OF BIODIVERSITY}

Living organisms vary at every level of the phylogenetic hierarchy from individual genes through higher taxa, and ecological assemblages vary in composition from guilds or functional groups, through communities, to landscapes. This variation is of interest in understanding ecosystem functioning insofar as it provides a proxy for variation in traits important to processes such as growth, production, and resource use (e.g. Norberg et al. 2001). Historically, most research exploring biodiversity effects on ecosystem functioning has equated 'biodiversity' with the number of species (Tilman 1999, Loreau et al. 2001). In principal, however, diversity at any level might influence ecosystem processes, and there is evidence that variation at several levels does so, as reviewed below.

Conceptually, diversity can be partitioned into variation in identity (often called composition in the BEF literature) and number (or richness) of elements, whether those elements are species, genotypes, or other enti- ties. It has long been recognized that the identities of species in a system strongly influence its functioning. Particular keystone species, dominant species, and ecosystem engineers have pervasive impacts on structure and functioning of a wide range of ecosystems (Jones et al. 1994, Power et al. 1996, Grime 1998). In seagrass systems, specifically, identity of the dominant seagrass and macroalgal species strongly influences sediment biogeochemistry, nutrient cycling, water-column oxygen profiles, water filtration capacity, primary and secondary production, carbon storage, support of higher trophic levels including commercially important species, and response to disturbance (Heck \& Orth 1980, Duarte 1991, Lemmens et al. 1996, Cebrián et al. 1997, Duarte et al. 1997, Valiela et al. 1997, Wigand et al. 1997, Lipcius et al. 1998, Hemminga \& Duarte 2000, Deegan et al. 2002). For example, shallow eutrophic estuaries are often dominated by macroalgae (Valiela et al. 1997), which support much sparser animal populations than seagrass beds (Deegan 2002). Experimental removal of macroalgae in a eutrophic estuary shifted dominance back to eelgrass Zostera marina, substantially enhancing abundances of fishes and decapod crustaceans, and reducing water-column hypoxia (Deegan et al. 2002). At a finer taxonomic scale, 4 Mediterranean seagrass species spanned an order of magnitude in the proportion of their production stored as refractory detritus (Cebrián et al. 1997), and a suite of Philippine seagrass species responded quite differently to experimental sediment loading, with some species declining rapidly, but others showing an opportunistic growth increase (Duarte et al. 1997).

Similarly, the identity of herbivore taxa is important to ecosystem processes; fishes and sea urchins often injure seagrasses by feeding on them, whereas most gastropods and crustaceans facilitate seagrasses by grazing their competitors (Hughes et al. 2004, Valentine \& Duffy 2005). Even superficially similar grazer taxa can have widely different impacts on the structure and functioning of seagrass systems (Duffy et al. 2003, 2005). In short, the ecosystem consequences of variation in species identity are well documented and uncontroversial for seagrass beds and other ecosystems.

The more challenging question is whether and how the richness or variety of elements (genotypes, species, habitat types) in a system influence its functioning. That is, are there general relationships between species richness and ecosystem processes, or are species effects entirely idiosyncratic? Under what circumstances might we expect diversity effects or idiosyncrasy? These and related questions have been a primary focus of recent research in ecology (reviewed by Tilman 1999, Loreau et al. 2001, 2002b, Kinzig et al. 
2002). The abundant functional variation among species in seagrass communities provides much raw material by which diversity might influence ecosystem properties. Accordingly, I focus here on whether and how the number (richness) of genotypes, species, higher taxa, and habitat types in seagrass systems influences production, trophic transfer, biogeochemical fluxes, and resistance to disturbance. Existing data suggest that biodiversity at a range of scales can significantly influence the functioning of seagrass ecosystems and enhances the magnitude and stability of services that they provide to humans.

\section{EVIDENCE AND INFERENCE}

Since much controversy has surrounded proposed relationships between biodiversity and ecosystem function (Huston 1997, Huston et al. 2000, Wardle et al. 2000), it is important to consider the nature of available evidence. A logical first pass at evaluating such relationships might involve mining the extensive datasets on community composition and rates of ecosystem processes available for marine systems. Emmerson \& Huxham (2002) used this approach in a thoughtful review of potential links between diversity and ecosystem properties in marine sedimentary systems. Using individual sites or studies as data points, they found positive correlations between benthic invertebrate species richness and ammonium flux, particle clearance from the water column, and secondary production. Using a similar approach, Duarte (2000) found that aggregate seagrass biomass and species richness of seagrasses covaried positively in southeast Asian beds.

While such relationships are intriguing, it is critical to bear in mind, as Emmerson \& Huxham (2002) noted, that correlation is not causation. Relationships between species diversity and productivity, for example, are bidirectional (Loreau et al. 2001, Naeem 2002, Worm \& Duffy 2003). Species richness varies predictably with resource availability, disturbance, and other abiotic gradients (Huston 1994). Typically, withinhabitat diversity increases as resource availability (productivity potential) increases from very low to moderate levels, above which excess nutrient loading can reduce diversity again (the 'paradox of enrichment', Rosenzweig 1971). The initially rising diversity is attributable in large part to the greater carrying capacity and favorability of more productive environments, which allows additional species to persist that could not do so under very low resource availability. Such cross-site comparisons explicitly consider a gradient in the abiotic environment and assume that a regional pool of species is available to colonize all sites.
In this scenario, then, one expects a positive correlation between aggregate biomass, which reflects carrying capacity, and diversity. However, it is because resource availability (environmental 'productivity') is driving diversity, rather than vice versa.

Studies of how biodiversity influences ecosystem processes address a very different question, namely the consequences o irreversible species loss from a system in which the abiotic environment is held constant. That is, they simulate the consequences of global or regional extinction. The distinction is critical, and has often been misunderstood. The most rigorous way to test this latter hypothesis is through experimental manipulation of biodiversity. In contrast, surveys of unmanipulated systems rarely can rigorously test whether diversity influences aggregate biomass (or other ecosystem processes) because, in open systems, diversity and biomass patterns are both responses to resource availability.

\section{THREATS TO BIODIVERSITY OF SEAGRASS ECOSYSTEMS}

Whether and how changing biodiversity influences ecosystem functioning obviously depend on which taxa are lost-and which are gained via invasion. Experiments (Jonsson et al. 2002, Zavaleta \& Hulvey 2004) and simulations (Ostfeld \& LoGiudice 2003, Solan et al. 2004) show that the identity and order in which species are lost from a system strongly influence how those losses translate to changing ecosystem functioning. Several patterns in how humans influence biodiversity appear to apply across a broad range of aquatic (and many terrestrial) systems (Fig. 1). Perhaps the most consistent is that overharvesting results in large animals being the first species to be lost, or rendered so rare as to be ecologically extinct (Jackson et al. 2001, Pandolfi et al. 2003, Lotze \& Milewski 2004). Thus, one of the first consequences of human impact on most ecosystems is 'trophic skew', i.e. flattening of the trophic biomass pyramid with general reduction in impacts of large predators (Duffy 2003). Such overharvesting followed rapidly after human occupation of sites worldwide, even with low human population densities and primitive hunting technologies (Jackson et al. 2001, Wing \& Wing 2001). Reduction of large animals can have several ecosystem-level consequences. Depending on the number and discreteness of effective trophic levels (Strong 1992), reduced predator abundance may actually increase grazing pressure via a trophic cascade. Such cascades have not yet been demonstrated conclusively in seagrass beds, but are documented or inferred in other coastal systems. For example, hunting of sea otters in the 19th century 

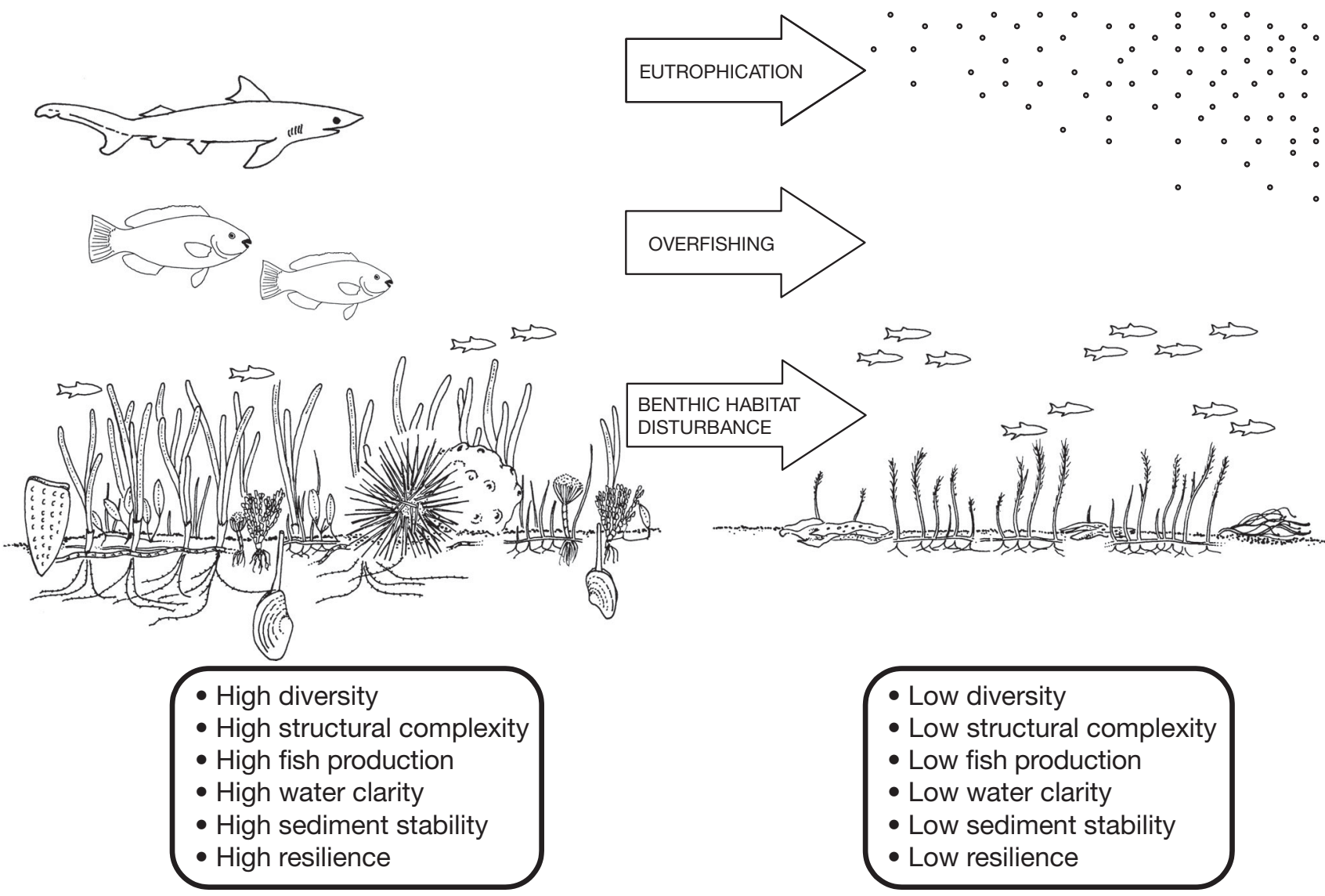

Fig. 1. Schematic illustration of major human-induced impacts on a tropical seagrass system, their common influences on biodiversity and habitat structure, and some of their consequences for ecosystem functioning

caused a phase shift from productive kelp beds to structureless sea urchin barrens (Estes \& Duggins 1995). Similarly, destructive grazing of salt-marsh cordgrass by abundant snails in the southeastern United States may have been exacerbated by overfishing of their main predator, the blue crab Callinectes sapidus (Silliman \& Bertness 2002). Finally, perennial seaweeds like rockweeds Fucus and giant kelp have occasionally been decimated by outbreaks of grazing crustaceans in recent decades (e.g. Kangas et al. 1982, Haahtela 1984, Tegner \& Dayton 1987), although the link to reduced predation has not been made conclusively in these cases. Because many large marine vertebrates are highly mobile, loss of these animals may also break important functional links between habitats that involve transport of materials or consumer influence (Polis et al. 1997, Lundberg \& Moberg 2002).

In modern coastal regions, anthropogenic habitat destruction and eutrophication (Fig. 1) are also nearly universal, and are major threats to seagrass systems (Short \& Wyllie-Echeverria 1996, Duarte 2002). Like harvesting, habitat destruction tends to influence large, slow-growing plants and animals most heavily, leading to dominance by opportunistic 'weedy' taxa with small bodies and fast growth (Watling \& Norse 1998). This loss of large plants and sessile invertebrates removes important habitat structure for associated mobile organisms. Moreover, since large species tend to have correspondingly large per-capita effects on ecosystem processes (Emmerson \& Raffaelli 2004, Solan et al. 2004), loss of large mobile invertebrates can reduce bioturbation, with important biogeochemical consequences (e.g. Aller \& Yingst 1978, 1985, Emmerson et al. 2004, Lohrer et al. 2004, Waldbusser et al. 2004, Widdicombe et al. 2004). Finally, eutrophication generally selects for fast-growing algae (including phytoplankton) over perennial seagrasses (Valiela et al. 1997). Hence, under human impact, biodiversity loss most severely affects large animals, high trophic levels, and perennial benthic plants. What is left are physically fragmented systems dominated by small, opportunistic species tolerant of various anthropogenic stressors (Fig. 1).

While human activities have reduced biodiversity through the mechanisms just discussed, they have also transported and established many species outside their 
native ranges, both intentionally and inadvertently. For example, the Asian seagrass Zostera japonica has become established on the northwest coast of North America, essentially converting intertidal mudflats into seagrass beds, and increasing benthic animal diversity, abundance, and sediment organic matter much as native seagrasses do (Posey 1988). Although such invasions often increase local species richness, at least in the short term (Sax \& Gaines 2003), exotic predators, disease organisms, and competitors also frequently have large detrimental impacts on the structure and functioning of native ecosystems (Simberloff et al. 2005), including seagrass systems. For example, invasion and aggressive growth of the non-indigenous alga Caulerpa taxifolia in the Mediterranean are threatening seagrass beds there (deVilléle \& Verlaque 1995). In California, USA, the exotic mussel Musculista senhousia reduces the rhizome extension rates of eelgrass Zostera marina, suggesting that these invaders might be particularly detrimental to eelgrass beds that have already been fragmented (Reusch \& Williams 1998).

\section{BIODIVERSITY AND FUNCTIONING OF SEAGRASS ECOSYSTEMS}

\section{Conceptual background}

Diversity and resource use and productivity

Theory predicts that declining biodiversity should reduce community resource use and productivity, alter trophic interactions, and reduce a system's stability in the face of natural and human-induced perturbations. Tilman (1999) has reviewed the theoretical basis, as well as the first generation of experiments supporting the influence of plant species diversity on resource use and productivity. Briefly, diverse assemblages are predicted to be more productive, on average, than species-poor assemblages, because their larger range of traits allows exploitation of a greater fraction of available resources (niche complementarity), and because diverse assemblages are more likely, by chance alone, to contain species that grow well under the local conditions (the sampling effect). Most manipulations of grassland plant diversity have supported these predictions (Hector et al. 1999, Tilman 1999), although there are conspicuous exceptions (Hooper \& Vitousek 1997, Pfisterer \& Schmid 2002) and debate continues over interpretation of results (e.g. Huston \& McBride 2002). While the theory was developed primarily for plants, it should apply in principle to competitive assemblages of any type of organism, and experiments have indeed shown that species richness also enhances efficiency of resource use by sessile marine invertebrates (Stachow- icz et al. 1999, 2002), stream suspension feeders (Cardinale et al. 2002), mobile grazers (Naeem \& Li 1998, Duffy et al. 2003), aquatic detritivores (Jonsson \& Malmqvist 2000), and heterotrophic bacteria (Naeem et al. 2000). Thus, the greater efficiency of resource use by more diverse assemblages appears to be a common phenomenon in a range of taxa and ecosystems.

\section{Diversity and trophic interactions}

Within a food web, biodiversity can be thought of as having 2 dimensions: a 'vertical' component summarized by the length of food chains and a 'horizontal' component representing the number of species or functional groups within trophic levels (Fig. 2). Changes in vertical diversity (e.g. food chain length) often strongly influence ecosystem properties through changing trophic interactions (e.g. Pace et al. 1999, Shurin et al. 2002, Borer et al. 2005). Horizontal diversity influences ecosystem functioning through competition, facilitation, and resource partitioning, topics which have been the focus of most of the previous BEF research (Kinzig et al. 2002, Loreau et al. 2002b). Lowdiversity systems often function approximately as simple linear food chains with strong trophic cascades, as shown in temperate lakes (Carpenter et al. 1985, Jones \& Sayer 2003), high-latitude kelp beds (Estes et al. 1998), and the boreal ocean (Worm \& Myers 2003). Higher-diversity systems, in contrast, are expected to show weaker cascades and weaker top-down control (Leibold 1989, 1996, Strong 1992). The reason is that more diverse assemblages contain a wider range of predator-resistant taxa, such that predation shifts dominance toward resistant species ('species turnover', Leibold 1996) rather than reducing aggregate prey biomass as in simple food chains (Duffy 2002). This buffering effect of diversity against top-down control is supported by a meta-analysis of periphyton-grazer experiments (Hillebrand \& Cardinale 2004), a metaanalysis of terrestrial trophic cascade experiments (Schmitz et al. 2000), data on parasitoid control in terrestrial food webs (Montoya et al. 2003), and an explicit experimental test in a seagrass system (Duffy et al. 2005). Conversely, the effects of changing predator diversity on aggregate prey biomass have received little study (Duffy 2002, but see Finke \& Denno 2004, Bruno \& O'Connor 2005). In general, available data suggest that increasing diversity within a trophic level (or other functional group) often increases that level's relative influence on ecosystem functioning, as it leads to both greater resource use and greater resistance to control by higher-order predators. Nevertheless, trophic cascades have been observed in several highly diverse systems (Pace et al. 1999, Borer et al. 2005), 


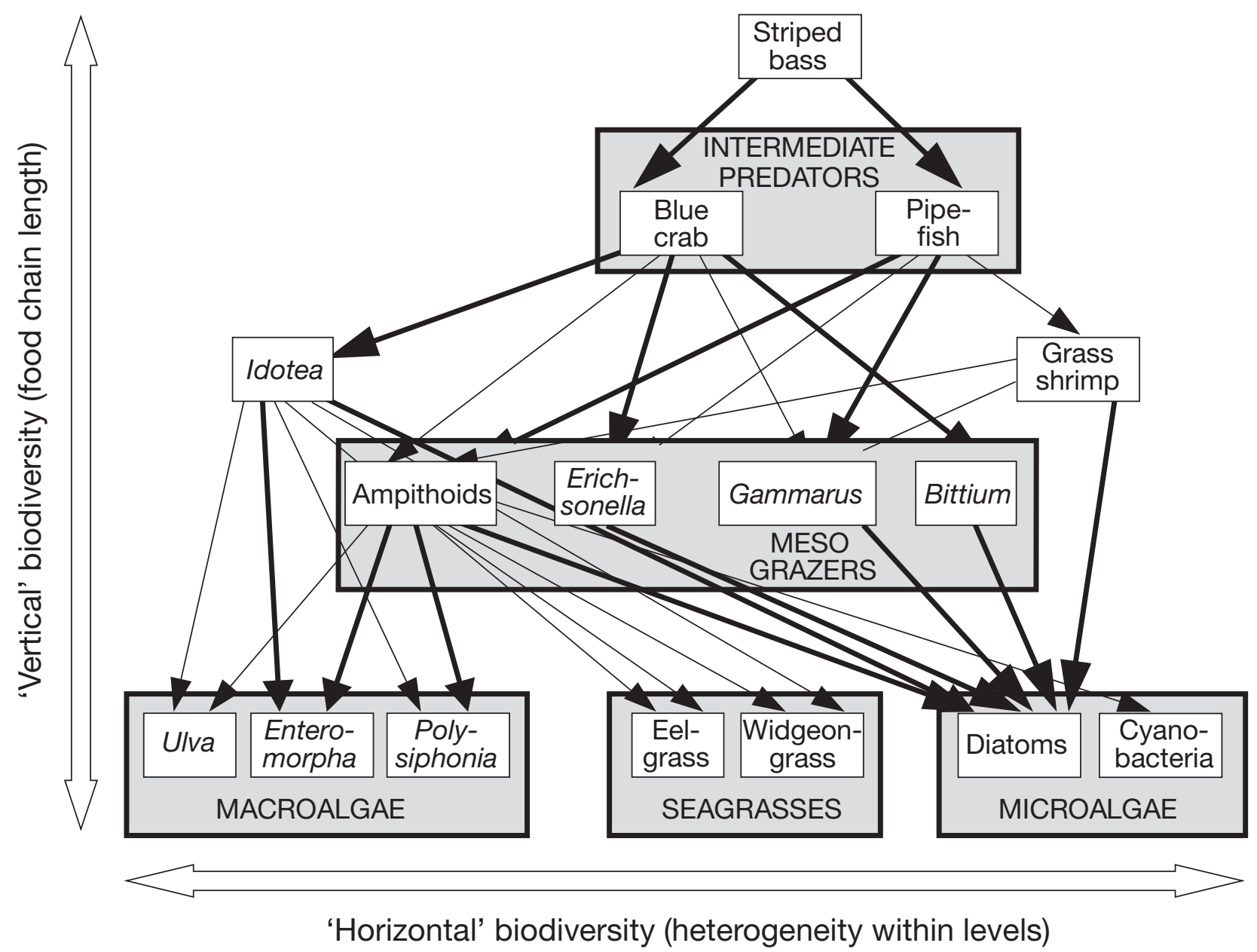

Fig. 2. Vertical (food chain length) and horizontal (heterogeneity) components of biodiversity, illustrated in a partial food web from an eelgrass bed (Zostera marina) in Chesapeake Bay, USA. Changes in biodiversity may influence ecosystem functioning via changes in food chain length (e.g. loss of predators), and thus in the strength of top-down control, by eliminating entire functional groups (gray rectangles), by changing species diversity within functional groups, or by interactions among these processes

confirming that keystone species and other strong interactors can override the potentially buffering effects of diversity in some situations.

\section{Diversity and stability}

Finally, biodiversity is hypothesized to enhance stability of aggregate ecosystem properties (e.g. total plant biomass) under changing environmental conditions (Naeem 1998, Yachi \& Loreau 1999), because functionally redundant species can provide insurance when any one species is lost and because variation among species in response to environmental change (response diversity, Elmqvist et al. 2003) can even-out temporal fluctuations in community biomass. Some terrestrial and aquatic microbial experiments support these predictions. For example, in experimental moss assemblages, more diverse plots showed greater resistance to drought stress, that is, aggregate biomass was less affected by drought than in lower-diversity plots (Mulder et al. 1999). In microbial microcosms, ecosystem biomass was more predictable under changing resource (light and nutrient) conditions when more species were present (Naeem \& Li 1998). In the marine benthos, experiments and surveys both showed that more diverse fouling assemblages were more resistant to invasion by non-indigenous species (Stachowicz et al. 1999, 2002). Thus, high diversity often appears to buffer against effects of disturbance in a variety of ecosystems.

\section{Special considerations in seagrass ecosystems}

The current themes of BEF research are based largely on research aimed at terrestrial plants. Although several ecosystem-level effects of diversity have been demonstrated in a variety of systems and 
taxa, understanding potential effects of biodiversity on functioning of seagrass and other marine ecosystems also requires recognizing their typically strong topdown control, strong species dominance, and discordance between biomass and productivity. First, the strong consumer pressure characteristic of many aquatic systems (Cyr \& Pace 1993, Shurin et al. 2002) and the special vulnerability of large marine predators (Pauly et al. 1998, Worm et al. 2005) mean that effects of changing diversity on marine ecosystem functioning will likely entail complex interactions of changing diversity within levels and changing food chain length (Duffy 2003, Duffy et al. 2005). Second, many temperate seagrass systems are dominated by 1 or a few foundation species, the characteristics of which are likely to dominate ecosystem processes (Grime 1998). In such cases we may expect, by analogy with the effects of species richness, that genetic and phenotypic diversity within foundation species will be important (Reusch \& Hughes 2006). Finally, the use of standing plant biomass as a proxy for plant production, as is typically done in terrestrial experiments, is inappropriate in aquatic algal-based systems, because much algal production is rapidly grazed (Cyr \& Pace 1993), resulting in poor correlations between biomass and productivity. Moreover, the existence of many aquatic macrophyte systems depends paradoxically on dominance of the least productive primary producer species in the community. Seagrasses generally have substantially lower biomass-specific productivity than marine macro- and microalgae, which outcompete them under eutrophication or relaxed grazing pressure (Valiela et al. 1997). Yet, seagrass beds typically support considerably higher secondary production than sediment bottoms dominated by more productive macroalgae (e.g. Klumpp et al. 1989, Deegan 2002), because seagrass beds provide more a favorable physical structure, which supports both growth of microalgal food and shelter from predators for small animals. Thus, plant species composition, rather than total productivity, is important to the functioning of seagrass ecosystems.

\section{Functional consequences of primary-producer species diversity}

In an early discussion of marine BEF linkages, Duarte (2000) summarized evidence for differences among seagrass species in growth capacity and response to disturbance, and argued that these differences should lead to enhanced productivity and stability in diverse tropical seagrass assemblages, as they do in some terrestrial grasslands (Hector et al. 1999, Tilman 1999). Although his discussion predated experimental tests of such links in marine systems, much circumstantial evidence is con- sistent with Duarte's suggestions. For example, in the Caribbean, co-occurring seagrass species differ in rooting depth, with Halodule and rhizophytic algae near the surface, Syringodium below, and Thalassia occupying the deepest layer (Williams 1990). This partitioning of the rooting zone may foster complementarity of resource use, and thus greater aggregate efficiency of resource use by the plant assemblage, as has been demonstrated experimentally in terrestrial grasslands (Tilman 1999, Hector et al. 1999).

Despite dominance of plant biomass in seagrass beds by 1 or a few seagrass species, macroalgae are also characteristic components of seagrass communities and can play important functional roles. Although macroalgal blooms can smother seagrasses under excess nutrient loading (Raffaelli et al. 1998, Hauxwell et al. 2001), macroalgae can also facilitate seagrass growth under normal, low-nutrient conditions. Two examples illustrate this role. First, field experiments in a Caribbean seagrass bed suggest that rhizophytic green algae facilitate seagrass recolonization of cleared plots because decomposition of below-ground algal tissues increases nutrient concentrations in these oligotrophic sediments (Williams 1990). Such apparent facilitation is reminiscent of that between legumes and grasses in terrestrial grasslands. Second, Caribbean turtlegrass Thalassia testudinum beds often support a dense understory of the calcareous alga Halimeda. In Puerto Rico, turtlegrass associated with Halimeda mounds was denser, and had higher biomass and productivity, than turtlegrass away from Halimeda; ${ }^{13} \mathrm{C}$ signatures of leaves growing from the mounds suggested that the calcareous alga elevated dissolved $\mathrm{CO}_{2}$ in the interstices of the mounds, enhancing turtlegrass productivity (Kenworthy \& Reid 2003). These examples suggest that facilitation and niche complementarity among co-occurring plant species in seagrass beds may enhance resource use and aggregate production above those found in more pure stands.

\section{Functional consequences of seagrass genetic diversity}

In communities with strong dominance, such as many seagrass beds, intraspecific genetic diversity within dominant species may enhance the species' performance by analogous mechanisms to the niche complementarity and facilitation among species discussed above (Reusch \& Hughes 2006). Several studies from seagrass systems support such effects. Williams (2001) tested how allelic diversity at the individual (or clone) level influenced eelgrass performance, transplanting eelgrass shoots of known allozyme genotypes into the field in southern California to achieve treatments with higher allelic diversity (heterozygous at 1 or both of 2 
loci) and lower allelic diversity (homozygous at both loci). The metabolic enzyme loci studied $(M D H$ and GPI-2) are known to be influenced by selection in other taxa, and thus may not be ideal proxies for genomewide genetic diversity. Nevertheless, the more heterozygous plots produced greater shoot density by the end of the 2 yr experiment. In a separate mesocosm experiment measuring eelgrass growth responses to temperature stress, heterozygous genotypes also showed lower variability among treatments than did homozygotes (Williams 2001). Finally, seeds from a genetically depauperate transplant site had lower germination success than those from a more genetically diverse bed.

The link between population genetic diversity and stability was demonstrated conclusively by a field experiment on the central California coast that established replicated eelgrass plots spanning a range in clonal diversity, identified using microsatellite markers, from 1 to 8 genotypes per plot (Hughes \& Stachowicz 2004). The ecological consequence of higher genotypic diversity in this experiment was expressed as enhanced eelgrass resistance to disturbance by grazing geese and the stress associated with transplantation, resulting in more stable seagrass biomass and higher abundances of invertebrates and other associated species. A similar positive effect of genotypic diversity on eelgrass performance was demonstrated in the North Sea (Reusch et al. 2005), where more diverse plots achieved higher biomass during the anomalously hot summer of 2003.

Fisher's fundamental theorem of natural selection states that the adaptive evolutionary potential of a population is proportional to its genetic diversity. The examples reviewed here show that genetic diversity can also be important to the population's ability to cope with environmental change in ecological time. High genetic diversity within populations of dominant seagrasses can enhance growth performance and stability in the face of perturbations; thus, maintenance of high genetic diversity within seagrass populations may be important to maintaining the normal structure and functioning of the ecosystems they support. Positive consequences of genotypic diversity within foundation species for system stability and performance also may be common in other systems with strong dominance such as salt marshes, kelp beds, oyster reefs, deep-sea coral reefs, and pelagic upwelling systems. This possibility has clear conservation implications and deserves further study.

\section{Functional consequences of consumer diversity}

Human impacts on marine communities generally begin with depletion of large vertebrate predators and herbivores (Fig. 1), reducing the vertical component of biodiversity (Fig. 2). The consequences of this depletion will be mediated via cascading trophic interactions. In seagrass systems, the impacts of depleted large vertebrates have been inferred largely from indirect evidence and are speculative (as is true in most other systems), but it seems clear that large vertebrates were formerly far more abundant, particularly in tropical seagrass ecosystems, than they are today. Historical records suggest, for example, that sea turtles, some of which feed primarily on seagrasses, were orders of magnitude denser in the Caribbean prior to European contact (Jackson et al. 2001), and probably imposed strong grazing pressure on tropical seagrass beds, as dugongs probably did in the Indo-Pacific (Domning 2001). In addition to such mega-herbivores, predatory fishes have been greatly reduced in most coastal and oceanic ecosystems (Pauly et al. 1998, Jackson et al. 2001, Myers \& Worm 2003, Worm \& Myers 2003). Comparisons with other systems suggest that these losses should cascade down to affect the structure and functioning of seagrass beds, although there is little hard evidence to evaluate the possibility (Williams \& Heck 2001).

The expected ecosystem consequences of changing consumer diversity are inherently more complex than those of changing plant diversity (Holt \& Loreau 2002, Thébault \& Loreau 2003). Whether effects of shortened food chains on seagrasses are primarily positive or negative will depend, for example, on the number and distinctness of links in the chain (Hairston et al. 1960, Strong 1992), on diet breadth of consumers (Duffy 2002), and on whether herbivores feed preferentially on seagrasses or their competitors. Herbivores in modern seagrass systems include both direct grazers on seagrasses, such as sea urchins, turtles, and some fishes, as well as grazers on epiphytes, which include most crustaceans and molluscs. Meta-analysis confirms that these 2 groups are functionally distinct, with negative and positive effects, respectively, on seagrass growth and production (Hughes et al. 2004). As epiphyte grazers tend to be more diverse and abundant than seagrass grazers, especially in modern temperate systems, grazing in many seagrass systems tends, on average, to favor seagrasses (Hughes et al. 2004) and facilitate their positive impacts on ecosystem services.

The strength of top-down control generally, and trophic cascades specifically, should also be influenced by diversity within trophic levels, i.e. the horizontal component of biodiversity (Fig. 2; Leibold 1996, Duffy 2002). Supporting these predictions, recent mesocosm experiments in an eelgrass system demonstrated that declining species richness of crustacean mesograzers decreased their aggregate impact on the resource (algae) and decreased mesograzer production, in parallel with patterns demonstrated under declining plant 
diversity (Duffy et al. 2003). Specifically, treatments with 1 or 3 grazer species imposed lower total grazing impact on algae and accumulated less grazer biomass (secondary production), on average, than assemblages of 6 grazer species (Duffy et al. 2003). In a subsequent experiment that added a third trophic level (juvenile blue crabs Callinectes sapidus), declining grazer diversity also reduced the grazer assemblage's average resistance to predation, because diverse assemblages more consistently contained grazer species that eluded capture (Duffy et al. 2005). The latter experiment illustrates the important point that biodiversity and food chain length (i.e. presence or absence of predators) interactively influence ecosystem functioning and that neither factor's impact is predictable in isolation. In general, grazer diversity effects on resource use and production were stronger in the presence of a predator (Duffy et al. 2005), suggesting that increasing diversity within a trophic level buffered that level from topdown control. Finally, in both experiments with and without predatory crabs, declining mesograzer diversity reduced the dominance of eelgrass over macroalgae and epiphytes (Duffy et al. 2003, 2005). Thus, in this eelgrass system, high diversity of epiphyte grazers enhanced both control of epiphytes and macroalgae and the production of crustacean biomass, a critical link in food chains to higher trophic levels.

\section{Biodiversity and stability}

Among the most important hypothesized benefits of biodiversity for ecosystem functioning is provision of insurance that stabilizes the system against natural and anthropogenic environmental change (Naeem 1998, Yachi \& Loreau 1999, Loreau et al. 2002a). This insurance is provided by variation among the species within a functional group in response to change, or response diversity (Elmqvist et al. 2003). Importantly, such species might be considered functionally redundant under 'normal' conditions, but their response diversity (i.e. greater range of functional response traits, Naeem \& Wright 2003) makes the diverse assemblage better able to cope with environmental change.

There is mounting evidence that both genetic diversity and species richness provide such response diversity against perturbations in seagrass systems. This is because species or genotypes that appear functionally redundant under some circumstances fill different roles under changing conditions, as illustrated by 2 experiments. First, in the experiment discussed previously, Hughes \& Stachowicz (2004) found no effect of eelgrass genotypic diversity on either eelgrass biomass or the associated faunal assemblage in the absence of disturbance, suggesting that the genotypes were func- tionally redundant under normal circumstances. The importance of genetic diversity only became evident after disturbance, as the genotypes responded differently to a pulse of intense goose grazing. Second, response diversity among peracarid grazer species was demonstrated experimentally in eelgrass mesocosms (Duffy et al. 2005). In the absence of predation, the 4 grazer species had similar and strong impacts on epiphyte biomass, that is, they were functionally redundant. In the presence of predatory crabs, however, epiphyte control differed widely among grazer species, because of their differential vulnerability to predation, and grazing efficiency was higher in more diverse grazer assemblages. Finally, non-experimental evidence for response diversity comes from the varied responses of co-occurring seagrass species to experimental burial (Duarte et al. 1997) and the shift in dominance from Zostera to Ruppia during the 1997/1998 El Niño-Southern Oscillation event in Southern California (Johnson et al. 2003). Such response diversity is likely to be especially important in maintaining the stability of ecosystem services as the pace of anthropogenic environmental change accelerates. Thus, 'functional redundancy' may often be a misleading concept (Loreau 2004), and maintaining multiple, superficially similar species within functional groups is important to insuring seagrass and other ecosystems against unexpected surprises.

\section{STRUCTURAL COMPLEXITY AND FUNCTIONING OF SEAGRASS ECOSYSTEMS}

\section{Patch-scale processes}

Diversity can also influence ecosystem processes through its effects on habitat physical structure or complexity, which pervasively influence ecological processes, including productivity, trophic transfer, and maintenance of species diversity. Several of these topics are especially pertinent and well studied in seagrass systems, and have recently been comprehensively reviewed (Bell et al. 2006).

Plant diversity and faunal production

Seagrasses are classic ecosystem engineers, transforming relatively monotonous sediment bottoms into structurally complex, diverse, and highly productive habitats (Fig. 1). In addition to the seagrasses themselves, seagrass beds often recruit macroalgae, sponges, corals, large bivalves, and other sessile invertebrates that are rare or absent on unvegetated bottoms. Structural complexity of seagrass beds derives from both the 
physical arrangement of seagrass units within bedsshoot density, leaf length, patch structure-and from the richness and identity of other co-occurring sessile organisms.

Structurally complex habitats support higher diversity of mobile organisms in a wide range of systems (e.g. Kohn 1967, Abele 1974, Kotler \& Brown 1988). Several lines of evidence, mostly indirect, suggest that diversity of primary producers and sessile invertebrates influences structural complexity and associated functioning of seagrass systems. Stoner \& Lewis (1985) found that the understory of calcareous algae (Halimeda) in a Caribbean turtlegrass bed roughly doubled the surface area available for epifaunal habitat, relative to pure stands of turtlegrass, and that epifaunal densities were accordingly higher in plots with Halimeda. Moreover, while aggregate abundance of epifauna appeared closely related to plant surface area across all plots, 8 of the 15 dominant crustacean species were more abundant (per unit surface area) in plots with Halimeda. Thus, seagrass plots with macroalgae supported epifaunal assemblages that differed both quantitatively and qualitatively from those in pure seagrass stands. Similarly, Parker et al. (2001) showed experimentally in Chesapeake Bay that epifaunal abundance in mixed stands of seagrasses and macroalgae was proportional to total plant surface area, but that epifaunal species differed in their associations with particular macrophyte species such that epifaunal diversity was only slightly higher in plots of mixed seagrass and macroalgal species. These results recall similarly significant but weak relationships between plant diversity and insect diversity in terrestrial grasslands (Siemann et al. 1998). As is often true, however, too much of a good thing can be detrimental: in eutrophic systems, fleshy macroalgae outcompete seagrasses, increase water-column hypoxia, and support reduced animal abundance and production (Deegan et al. 2002).

Roles of sessile invertebrates

In tropical seas, sessile invertebrates are characteristic features of seagrass landscapes. Sponges, in particular, fulfill several important functions in these systems. These suspension feeders can have very high rates of water clearance, and symbiotic bacteria in some species make them disproportionately important to element cycling. Incubations of 4 common Caribbean sponges yielded the highest mass-specific rates of dissolved inorganic nitrogen production yet recorded from a benthic community (Diaz \& Ward 1997), and suggest that sponge-mediated nitrification may be substantial in shallow tropical environments where they are abundant. Sponges also provide unique and important physical habitat in seagrass systems, and many animals shelter within and under large sponges. A dramatic example of the importance of sponges became evident after the ecosystem phase shift that affected Florida Bay, USA, in the early 1990s. Large areas affected by blooms of planktonic cyanobacteria suffered severe mortality of sponges, thus losing critical shelter habitat for juvenile spiny lobsters and other animals; as a result, abundance of lobsters, which constitute a valuable fishery resource, declined wherever artificial shelters were unavailable (Butler et al. 1995).

\section{Habitat complexity and trophic transfer}

Among the most important and well-studied ecosystem services provided by seagrass beds is the provision of habitat for small animals and, thus, the enhancement of secondary production. A rich history of research shows that increasing seagrass structural complexity enhances epifaunal abundance and production, but conversely decreases the efficiency by which that production is transferred to predators (reviewed by Heck \& Orth 1980, 2006). This research has focused primarily on the role of seagrass density (often referred to as 'complexity') in mediating predator-prey interactions, but there is also evidence that species of seagrasses and macroalgae differ in the total density, and species relative abundances, of associated epifauna they support (Lewis 1987, Virnstein \& Howard 1987a,b, Jernakoff \& Nielsen 1998, Parker et al. 2001). Experiments have illuminated the mechanistic bases for these relationships, showing that variation among plant species in epifaunal density is largely, but not entirely, explained by plant surface area (Stoner \& Lewis 1985, Parker et al. 2001). Experiments also suggest that the relationship between seagrass density and effectiveness of predation is non-linear (reviewed by Heck \& Orth 2006), a conclusion also reached for juvenile decapod prey sheltering among macroalgae in seagrass beds (Lipcius et al. 1998). Although debate continues on the precise form of relationships between plant density and predation rate, it seems clear that some threshold density of vegetation is usually necessary to reduce predation rates on epifauna. Recent experiments on oyster reefs add an intriguing twist, indicating that at high predator densities, predation may be more, rather than less, effective in complex habitats, because habitat complexity reduces interference competition among predators (Grabowski \& Powers 2004). A central challenge for future research is determining how the higher densities of both prey and predators in denser seagrass interact with reduced per capita effectiveness of predators to mediate trophic transfer (Heck \& Orth 2006). 


\section{Landscape diversity}

Research in a wide range of systems demonstrates that interactions among the communities of different habitats in a landscape, mediated by both migrations of organisms and advection of resources, can profoundly influence community structure and ecosystem functioning (Polis et al. 1997, 2004). Such landscape diversity should be especially important to the functioning of marine systems, because they tend to be much more open than terrestrial systems (Witman et al. 2004, Heck \& Orth 2006).

\section{Seagrass patch structure}

The most basic aspect of landscape structure in seagrass systems involves the arrangement of seagrass patches relative to the matrix of unvegetated sediment area. Seagrasses are patchily distributed at a wide range of spatial scales, and there has accordingly been substantial research on the role of patch size and structure on associated animals and trophic interactions (Bell et al. 2006). Evidence to date suggests that relationships between patch size and animal abundance are idiosyncratic, and few consistent patterns have emerged (Bell et al. 2006). Nevertheless, several studies support the hypothesis that seagrass patch edges can act as ecotones where both epifaunal settlement and predation are elevated, potentially enhancing trophic transfer. In turtlegrass beds in the Gulf of Mexico, USA, density and estimated production of invertebrates was greater at the edges than in the interiors of patches (Bologna \& Heck 2002). Both adult peracarids in turtlegrass (Bologna \& Heck 2000) and newly settled sessile invertebrates in eelgrass (Orth 1992) were more abundant near patch edges, suggesting that abundance is determined in part by encounter rates of drifting larvae with seagrass, creating settlement shadows in the interior of patches. Predation also commonly appears to be elevated in patchy seagrass landscapes, as is also true in many terrestrial ecosystems (e.g. Hartley \& Hunter 1998, Chalfoun et al. 2002). Experiments have demonstrated elevated predation rates on juvenile blue crabs in seagrass patches separated by large expanses of sand (Hovel \& Lipcius 2002), and clams and scallops also showed lower survival in patchy than in continuous seagrass beds (Irlandi 1994, Irlandi et al.1995). These results suggest that trophic transfer is often elevated along patch edges and in fragmented seagrass landscapes relative to continuous ones.

\section{Cross-habitat subsidies}

Many community and ecosystem processes are strongly affected by connections between different kinds of habitats. These effects can result from passive advection of propagules and resources, or from active movement of mobile predators among habitats. A striking example is the subsidy of deep-sea food webs by seagrass leaves advected away from tropical islands (Suchanek et al. 1985). Seagrass beds may also be recipients of advected material, as exemplified by the high diversity and biomass of epiphytic macroalgae measured on seagrasses near reefs in Western Australia (Van Elven et al. 2004). By recruiting propagules from both habitats, near-reef seagrasses supported $20 \%$ higher algal diversity than on the adjacent reef, and $43 \%$ higher diversity than on seagrasses distant from the reef. Epiphytic algal biomass on near-reef seagrasses was $>3$-fold greater than on the reefs, and nearly 6 -fold higher than on distant seagrasses.

Active movement of predators between habitats can enhance densities and direct impacts of predators, and enhance primary producer growth indirectly via transport and excretion of inorganic nutrients by migrating predators. As an example of the first type of process, pinfish were more abundant in salt marshes adjoining seagrass beds than in marshes without seagrass beds (Irlandi \& Crawford 1997). Similarly, Micheli \& Peterson (1999) showed that oyster reefs isolated from seagrass beds and salt marshes supported higher macroinvertebrate species richness and higher survival of transplanted clams than reefs adjacent to vegetated areas. Experiments demonstrated that surrounding vegetation served as corridors facilitating access by predatory blue crabs to oyster reefs. Hence, in this instance, landscape-level diversity enhanced the strength of top-down control. The second process, transport of nutrients among habitats, was documented by Meyer et al. (1983). They showed that haemulid fishes (grunts) fed on invertebrates in seagrass beds by day and, during the night, moved to shelters among coral heads, where their excretion fertilized nutrient-limited corals and enhanced their growth rates. Subsidies moving in the opposite direction, into seagrass beds, are mediated by piscivorous birds that deposit nitrogen-rich guano near their roosts; seagrass beds surrounding bird islands had higher seagrass biomass and different seagrass species composition than islands without bird colonies (Powell et al. 1991).

Habitat diversity and complex life histories

A major functional consequence of landscape diversity derives from the complex ontogenic habitat shifts characteristic of many large marine animals with longlived larvae. Tropical seagrass and mangrove habitats serve as nursery areas for many fishes that live as 
adults on nearby reefs. Thus, proximity of different habitats in the landscape is critical to the populations of these fishes. As a specific example, comparisons of otherwise similar Belizean reef islands with and without fringing mangroves showed that biomass of several commercially important reef fishes was more than twice as great on the reefs adjacent to mangrove nurseries (Mumby et al. 2004). Size-frequency distributions indicated that mangroves served as a way-station between larval settlement into seagrass habitats and migration to adult reef habitat. Most striking is the case of Scarus guacamaia, the largest herbivorous fish in the Atlantic, whose juveniles were found only among mangroves; this species has suffered extinction on several reefs after mangrove removal (Mumby et al. 2004). A similar phenomenon has been implicated for spiny lobsters that recruit into seagrass beds and eventually migrate to reefs and mangrove habitats, where they live as adults. Acosta (1999) found that mangrove and coral islands surrounded by seagrass supported higher lobster densities, and higher proportions of juvenile size classes, than islands surrounded by unvegetated rubble. The seagrass habitats apparently served as safe migration corridors for juvenile lobsters, since measured emigration and immigration rates were 3 to 4 times higher on islands surrounded by seagrass.

These results from seagrass beds associated with oyster reefs, coral reefs, salt marshes, and mangroves illustrate that landscape diversity - the variety and arrangement of different habitats in a landscape-can strongly affect population dynamics of key species, primary and secondary production, and trophic transfer, including productivity and stability of commercially important species.

\section{CONCLUSIONS AND FUTURE DIRECTIONS}

\section{Implications for conservation and management}

Human activities have strong and direct negative impacts on the functioning of ecosystems (Sala et al. 2000, Foley et al. 2005), including seagrass beds (Short \& Wyllie-Echeveria 1996, Duarte 2002). Changes in ecosystem functioning mediated indirectly by changing biodiversity are likely to be modest compared with these strong direct effects (Srivastava \& Vellend 2005). Nevertheless, over the long term, the capacity of ecosystems to continue adapting to environmental change must ultimately be compromised by continuing extinctions of species. Empirical research reviewed here suggests that biodiversity at a hierarchy of scales can influence the stable functioning of seagrass systems and the several services they provide to humans. These results have several practical implications. First, evidence that genetic diversity enhances seagrass growth and resistance to disturbance supports arguments that seagrass mitigation and restoration efforts should strive to minimize the genetic bottlenecks common to such programs (Williams 2001). Genetic diversity within populations is demonstrably important, not only to the long-term evolutionary potential of a species, but also for flexibility in the face of environmental change on ecological time scales ('resilience' in the parlance of Holling 1973). Because dominant species, such as seagrasses in many low-diversity temperate beds, have pervasive bottom-up influences on associated communities, genetic diversity within such species can influence the structure and functioning of entire ecosystems (Whitham et al. 2003, Reusch \& Hughes 2006). Experiments also show that resistance to perturbations can be fostered by response diversity among otherwise similar species, cautioning that 'functional redundancy' can be a misleading concept (Loreau 2004). Conservation measures that result in maintaining multiple species within functional groups (e.g. of seagrasses, grazers, or fishes) should provide seagrass beds with some insurance against impacts of environmental change.

There is growing evidence that trophic interactions can have important stabilizing and stimulating effects on ecosystem processes in many systems, i.e. that vertical diversity is functionally important. In seagrass beds specifically, epiphyte grazers have impacts on seagrasses that are comparable in magnitude, but opposite in sign, to those of the water-column nutrient loading widely recognized as a major threat to seagrass systems (Williams \& Ruckelshaus 1993, Heck et al. 2000, Hughes et al. 2004). As diverse assemblages of algal grazers are both more efficient consumers and more resistant to predator control, on average (Duffy et al. 2003, 2005), biodiversity at the grazer level may also benefit seagrass systems. Vertical diversity can also be important in reducing exotic invasions; in California, USA, native predatory snails killed $95 \%$ of the exotic mussels Musculista senhousia in native eelgrass beds, and preferentially attacked these invaders over native bivalve prey (Reusch 1998). These patterns underscore the premium on understanding how changing foodweb structure affects the structure and functioning of seagrass ecosystems (Williams \& Heck 2001, Hughes et al. 2004, Valentine \& Duffy 2005).

Finally, the interactions among communities of different habitats within a landscape, and particularly the complex, spatially distributed life histories of many commercially important tropical fishes and decapods, emphasize the importance of a landscape-level perspective in conserving both biodiversity and marine ecosystem services. Landscapes and species are mutually related, as large consumers serve as mobile links 
between habitats, and loss of those consumers can disrupt essential cross-habitat resource subsidies or important top-down control mediated by animals visiting from other habitats (Polis et al. 1997, Lundberg \& Moberg 2002). Humans, of course, are the ultimate 'mobile link' species, and our activities often have unanticipated consequences at landscape and regional scales, such as the increased hunting pressure on endangered African forest animals when overexploitation reduced fishery production in adjacent marine waters (Brashares et al. 2004).

\section{Future research priorities}

\section{Scaling up}

Some of the most pressing priorities for research to understand seagrass systems are common to ecology and conservation as a whole. One critical, general challenge for ecology is finding creative and rigorous means of scaling up understanding based on small-plot experiments to the large scales over which marine population and community processes typically occur (see Naeem 2006, in this Theme Section). As one example, small-scale mesocosm experiments show that invertebrate grazers can counteract the negative effects of eutrophication on seagrass systems by cropping the increased algal biomass (reviewed by Hughes et al. 2004). In nature, however, this grazer control may be reduced by emigration of highly mobile grazers in search of more favorable habitat (Christie \& Kraufvelin 2003) and by shifts in dominance from epiphytic microalgae to macroalgae, which negatively affect dissolved oxygen in the water column and reduce grazer abundance (Deegan et al. 2002). While there is a continuing need for controlled experiments to identify mechanisms of diversity effects on ecosystem functioning, there is an even greater need for creative approaches, such as rigorous comparative studies, exploitation of 'natural experiments', and community modeling (e.g. Estes et al. 1998, Terborgh et al. 1999, Dulvy et al. 2004, Mumby et al. 2004, Ebenman \& Jonsson 2005) to evaluate the effects of changing biodiversity at the ecosystem scale.

\section{Realistic scenarios of biodiversity loss (and gain)}

A second frontier for BEF research involves developing experimental designs that incorporate realistic trajectories of biodiversity change. Several non-marine experiments have shown that preferential extinction of species with particular traits (e.g. large body size, sensitivity to pollutants) produces quite different changes in ecosystem functioning than does random species loss (Jonsson et al. 2002, Ostfeld \& LoGiudice 2003, Zavaleta \& Hulvey 2004). An obvious part of most extinction trajectories is the loss of large consumers (Duffy 2003, Worm et al. 2005). Thus, BEF research would profit from hybridization with food-web and predator-prey ecology (Duffy 2002, Worm \& Duffy 2003, Ives et al. 2005, Ebenman \& Jonsson 2005), again exploiting 'natural experiments' as well as research opportunities provided by the return of large predators in marine protected areas (Palumbi 2001, Micheli \& Halpern 2005). Moreover, while BEF research has focused almost exclusively on loss of species, an equally pressing concern is the gain of exotic species, which can have pervasive effects on ecosystems. Species loss and gain are often coupled, in that interactions with non-native species are a leading cause of extinction and endangerment of native species (Czech \& Krausman 1997, Clavero \& Garcia-Berthou 2005). Developing a rigorous ecological understanding of the causes and consequences of invasion (Sax et al. 2005) and of how invasion is affected by native species richness (Levine \& D'Antonio 1999, Stachowicz \& Tilman 2005) will be important in predicting ecosystem-level consequences of changing biodiversity.

\section{Landscape interactions}

Other research priorities are more specific to marine ecosystems, or seagrass ecosystems specifically. The openness of marine systems, characterized by relatively long-distance advection of materials and larvae and by long-distance migration of many large vertebrates, challenges ecologists to incorporate metapopulation, meta-community, and regional perspectives into BEF research. Ecological theory has begun to do so (Holt \& Loreau 2002, Loreau et al. 2003, Holt 2004). Most importantly, theory shows that the relationship of community structure generally, and diversity specifically, to ecosystem functioning depends strongly on the overall degree of openness and the relative openness at different trophic levels (Holt 2004). There is a need to understand better how qualitatively distinct habitat types, such as seagrass beds and coral or oyster reefs, interact within landscapes. As summarized above, such linkages are probably important in most marine systems.

Acknowledgements. I thank M. Solan for the invitation to contribute to the special Theme Section; the NCEAS Working Group on Marine Biodiversity and Ecosystem Services for stimulating discussion; J. Bruno, E. Canuel, J. Douglass, K. France, P. Richardson, A. Spivak, J. Stachowicz, and B. Worm for discussions that influenced my thinking, J. Douglass and 3 
anonymous reviewers for comments that improved the MS, and the NSF for support (OCE 00-99226 and 03-52343). This paper is Contribution \# 2729 from the Virginia Institute of Marine Science.

\section{LITERATURE CITED}

Abele LG (1974) Species diversity of decapod crustaceans in marine habitats. Ecology 55:156-161

Acosta CA (1999) Benthic dispersal of Caribbean spiny lobsters among insular habitats: implications for the conservation of exploited marine species. Conserv Biol 13(3):603-612

Aller RC, Yingst JY (1978) Biogeochemistry of tubedwellings: a study of the sedentary polychaete Amphitrite ornata (Leidy). J Mar Res 36:201-254

Aller RC, Yingst JY (1985) Effects of the marine depositfeeders Heteromastis filiformis (Polychaeta), Macoma baltica (Bivalvia), and Tellina texana (Bivalvia) on averaged sedimentary solute transport, reaction rates, and microbial distributions. J Mar Res 43:615-645

Anderson EA (1989) Economic benefits of habitat restoration: seagrass and the Virginia hard-shell blue crab fishery. N Am J Fish Manage 9:140-149

Bell SS, Foneseca MS, Stafford NB (2006) Seagrass ecology: new contributions from a landscape perspective. In: Larkum AWD, Orth RJ, Duarte CM (eds) Seagrasses: biology, ecology, and conservation. Springer, New York, p 625-645

Bologna PAX, Heck KL Jr (2000) Impacts of seagrass habitat architecture on bivalve settlement. Estuaries 23:449-457

Bologna PAX, Heck KL Jr (2002) Impact of habitat edges on density and secondary production of seagrass-associated fauna. Estuaries 25:1033-1044

Borer ET, Seabloom EW, Shurin JB, Anderson KE, Blanchette CA, Broitman B, Cooper SD, Halpern BS (2005) What determines the strength of a trophic cascade? Ecology 86: 528-537

Brashares JS, Arcese P, Sam MK, Coppolillo PB, Sinclair ARE, Balmford A (2004) Bushmeat hunting, wildlife declines, and fish supply in West Africa. Science 306:1180-1183

Bruno JF, O'Connor MI (2005) Cascading effects of predator diversity and omnivory in a marine food web. Ecol Lett 8: 1048-1056

Butler MJ IV, Hunt JH, Herrnkind WF, Childress MJ and 5 others (1995) Cascading disturbances in Florida Bay, USA: cyanobacteria blooms, sponge mortality, and implications for juvenile spiny lobsters Panulirus argus. Mar Ecol Prog Ser 129:119-125

Cardinale BJ, Palmer MA, Collins SL (2002) Species diversity enhances ecosystem functioning through interspecific facilitation. Nature 415:426-429

Carlton JT, Geller JB, Reaka-Kudla M, Norse EA (1999) Historical extinctions in the sea. Annu Rev Ecol Syst 30: 515-538

Carpenter SR, Kitchell JF, Hodgson JR (1985) Cascading trophic interactions and lake productivity. BioScience 35: 634-639

Cebrián J, Duarte CM, Marba N, Enriquez S (1997) Magnitude and fate of the production of four co-occurring western Mediterranean seagrass species. Mar Ecol Prog Ser 155:29-44

Chalfoun AD, Thompson FR, Ratnaswamy MJ (2002) Nest predators and fragmentation: a review and meta-analysis. Conserv Biol 16:306-318

Christie H, Kraufvelin P (2003) Mechanisms regulating amphipod population density within macroalgal commu- nities with low predator impact. Sci Mar 68(Suppl 1): 189-198

Clavero M, Garcia-Berthou E (2005) Invasive species are a leading cause of animal extinctions. Trends Ecol Evol 20: 110

Cloern JE (2001) Our evolving model of the coastal eutrophication problem. Mar Ecol Prog Ser 210:223-253

Costanza R, d'Arge R, de Groot R, Farber S and 9 others (1997) The value of the world's ecosystem services and natural capital. Nature 387:253-260

Cyr H, Pace ML (1993) Magnitude and patterns of herbivory in aquatic and terrestrial ecosystems. Nature 361:148-150

Czech B, Krausman PR (1997) Distribution and causation of species endangerment in the United States. Science 277: 1116-1117

Deegan LA (2002) Lessons learned: the effects of nutrient enrichment on the support of nekton by seagrass and salt marsh ecosystems. Estuaries 25:727-742

Deegan LA, Wright A, Ayvazian SG, Finn JT, Golden H, Merson RR, Harrison J (2002) Nitrogen loading alters seagrass ecosystem structure and support of higher trophic levels. Mar Freshw Ecosyst 12:193-212

deVilléle X, Verlaque M (1995) Changes and degradation in a Posidonia oceanica bed invaded by the introduced tropical alga Caulerpa taxifolia in the north western Mediterranean. Bot Mar 38:79-87

Diaz MC, Ward BB (1997) Sponge-mediated nitrification in tropical benthic communities. Mar Ecol Prog Ser 156: 97-107

Domning DP (2001) Sirenians, seagrasses, and Cenozoic ecological change in the Caribbean. Palaeogeogr Palaeoclimatol Palaeoecol 166:27-50

Duarte CM (1991) Allometric scaling of seagrass form and productivity. Mar Ecol Prog Ser 77:289-300

Duarte CM (2000) Marine biodiversity and ecosystem services: an elusive link. J Exp Mar Biol Ecol 250:117-131

Duarte CM (2002) The future of seagrass meadows. Environ Conserv 29:192-206

Duarte CM, Cebrián J (1996) The fate of marine autotrophic production. Limnol Oceanogr 41:1758-1766

Duarte CM, Chiscano CL (1999) Seagrass biomass and production: a reassessment. Aquat Bot 65:159-174

Duarte CM, Terrados J, Agawin, NSR, Fortes MD, Bach S, Kenworthy WJ (1997) Response of a mixed Philippine seagrass meadow to experimental burial. Mar Ecol Prog Ser 147:285-294

Duffy JE (2002) Biodiversity and ecosystem function: the consumer connection. Oikos 99:201-219

Duffy JE (2003) Biodiversity loss, trophic skew, and ecosystem functioning. Ecol Lett 6:680-687

Duffy JE, Canuel EA, Richardson JP (2003) Grazer diversity and ecosystem functioning in seagrass beds. Ecol Lett 6 : $1-9$

Duffy JE, Richardson JP, France KE (2005) Ecosystem consequences of diversity depend on food chain length in estuarine vegetation. Ecol Lett 8:301-309

Dulvy NK, Freckleton RP, Polunin NVC (2004) Coral reef cascades and the indirect effects of predator removal by exploitation. Ecol Lett 7:410-416

Ebenman B, Jonsson T (2005) Using community viability analysis to identify fragile systems and keystone species. Trends Ecol Evol 20:568-575

Elmqvist T, Folke C, Nyström M, Peterson G, Bengtsson J, Walker B, Norberg J (2003) Response diversity, ecosystem change, and resilience. Front Ecol Environ 1:488-494

Emmerson MC, Huxham M (2002) How can marine ecology contribute to the biodiversity-ecosystem functioning 
debate? In: Loreau M, Naeem S, Inchausti P (eds) Biodiversity and ecosystem functioning: synthesis and perspectives. Oxford University Press, New York, p 139-146

Emmerson MC, Raffaelli D (2004) Predator-prey body size, interaction strength and the stability of a real food web. J Anim Ecol 73:399-409

Emmerson MC, Solan M, Emes C, Paterson DM, Raffaelli D (2004) Consistent patterns and the idiosyncratic effects of biodiversity in marine systems. Nature 411:73-77

Estes JA, Duggins DO (1995) Sea otters and kelp forests in Alaska: generality and variation in a community paradigm. Ecol Monogr 65:75-100

Estes JA, Tinker MT, Williams TM, Doak DF (1998) Killer whale predation on sea otters linking oceanic and nearshore ecosystems. Science 282:473-476

Finke DL, Denno RF (2004) Predator diversity dampens trophic cascades. Nature 429:407-410

Foley JA, DeFries R, Asner GP, Barford C and 15 others (2005) Global consequences of land use. Science 309:570-574

Grabowski JH, Powers SP (2004) Habitat complexity mitigates trophic transfer on oyster reefs. Mar Ecol Prog Ser 277:291-295

Grime JP (1998) Benefits of plant diversity to ecosystems: immediate filter and founder effects. J Ecol 86:902-910

Haahtela I (1984) A hypothesis of the decline of the bladder wrack (Fucus vesiculosus L.) in SW Finland in 1975-1981. Limnologica 15:345-350

Hairston NG, Smith FE, Slobodkin LG (1960) Community structure, population control, and competition. Am Nat 94: 421-425

Hartley MJ, Hunter ML Jr (1998) A meta-analysis of forest cover, edge effects, and artificial nest predation rates. Conserv Biol 12:465-469

Hauxwell J, Cebrián J, Furlong C, Valiela I (2001) Macroalgal canopies contribute to eelgrass (Zostera marina) decline in temperate estuaries. Ecology 82:1007-1022

Heck KL Jr, Orth RJ (1980) Seagrass habitats: the roles of habitat complexity, competition and predation in structuring associated fish and motile macroinvertebrate assemblages. In: Kennedy VS (ed) Estuarine perspectives. Academic Press, New York, p 449-464

Heck KL Jr, Orth RJ (2006) Predation in seagrass meadows. In: Larkum AWD, Orth RJ, Duarte CM (eds) Seagrasses: biology, ecology, and conservation. Springer, New York, p 537-550

Heck KL Jr, Pennock JR, Valentine JF, Coen LD, Sklenar SA (2000) Effects of nutrient enrichment and small predator density on seagrass ecosystems: an experimental assessment. Limnol Oceanogr 45:1041-1057

Heck KL Jr, Hays C, Orth RJ (2003) Critical evaluation of the nursery role hypothesis for seagrass meadows. Mar Ecol Prog Ser 253:123-136

Hector A, Schmid B, Beierkuhnlein C, Caldeira MC and 30 others (1999) Plant diversity and productivity experiments in European grasslands. Science 286:1123-1127

Hemminga MA, Duarte CM (2000) Seagrass ecology. Cambridge University Press, New York

Hillebrand H, Cardinale BJ (2004) Consumer effects decline with prey diversity. Ecol Lett 7:192-201

Holling CS (1973) Resilience and stability of ecological systems. Annu Rev Ecol Syst 4:1-23

Holt RD (2004) Implications of system openness for local community structure and ecosystem function. In: Polis GA, Power ME, Huxel GR (eds) Food webs at the landscape level. University of Chicago Press, Chicago, p 96-114

Holt RD, Loreau M (2002) Biodiversity and ecosystem functioning: the role of trophic interactions and the importance of system openness. In: Kinzig AP, Pacala SW, Tilman D (eds) The functional consequences of biodiversity. Princeton University Press, Princeton, p 246-262

Hooper DU, Vitousek PM (1997) The effects of plant composition and diversity on ecosystem processes. Science 277: 1302-1305

Hovel KA, Lipcius RN (2002) Effects of seagrass habitat fragmentation on juvenile blue crabs survival and abundance. J Exp Mar Biol Ecol 271:75-98

Howarth R, Anderson D, Cloern J, Elfring C and 7 others (2000) Nutrient pollution of coastal rivers, bays, and seas. Issues Ecol 7:1-15

Hughes AR, Stachowicz JJ (2004) Genetic diversity enhances the resistance of a seagrass ecosystem to disturbance. Proc Natl Acad Sci USA 101:8998-9002

Hughes AR, Bando KJ, Rodriguez LF, Williams SL (2004) Relative effects of grazers and nutrients on seagrasses: a meta-analysis approach. Mar Ecol Prog Ser 282:87-99

Huston MA (1994) Biological diversity. The coexistence of species on changing landscapes. Cambridge University Press, New York

Huston MA (1997) Hidden treatments in ecological experiments: re-evaluating the ecosystem function of biodiversity. Oecologia 110:449-460

Huston MA, McBride AC (2002) Evaluating the relative strengths of biotic versus abiotic controls on ecosystem processes. In: Loreau M, Naeem S, Inchausti P (eds) Biodiversity and ecosystem functioning. Synthesis and perspectives. Oxford University Press, Oxford, p 47-60

Huston MA, Aarssen LW, Austin MP, Cade BS and 8 others (2000) No consistent effect of plant diversity on productivity. Science 289:1255 (abstract)

Irlandi EA (1994) Large- and small-scale effects of habitat structure on rates of predation: how percent coverage of seagrass affects rates of predation and siphon nipping on an infaunal bivalve. Oecologia 98:176-183

Irlandi EA, Crawford MK (1997) Habitat linkages: the effect of intertidal salt marshes and adjacent subtidal communities on abundance, movement, and growth of an estuarine fish. Oecologia 110:222-230

Irlandi EA, Ambrose WG, Orlando BA (1995) Landscape ecology and the marine environment: how spatial configuration of seagrass habitat influences growth and survival of the bay scallop. Oikos 72:307-313

Ives AR, Cardinale BJ, Snyder WE (2005) A synthesis of subdisciplines: predator-prey interactions, and biodiversity and ecosystem functioning. Ecol Lett 8:102-116

Jackson JBC, Kirby MX, Berger WH, Bjorndal KA and 15 others (2001) Historical overfishing and the recent collapse of coastal ecosystems. Science 293:629-638

Jernakoff P, Nielsen J (1998) Plant-animal associations in two species of seagrasses in Western Australia. Aquat Bot 60: 359-376

Johnson MR, Williams SL, Lieberman CH, Solbak A (2003) Changes in the abundance of the seagrasses Zostera marina L. (eelgrass) and Ruppia maritime L. (widgeiongrass) in San Diego, California, following an El Niño event. Estuaries 26:106-115

Jones CG, Lawton JJ, Shachak M (1994) Organisms as ecosystem engineers. Oikos 69:373-386

Jones JI, Sayer CD (2003) Does the fish-invertebrate-periphyton cascade precipitate plant loss in shallow lakes? Ecology 84:2155-2167

Jonsson M, Malmqvist B (2000) Ecosystem process rate increases with animal species richness: evidence from leaf-eating, aquatic insects. Oikos 89:519-523

Jonsson M, Dangles O, Malmqvist B, Guerold F (2002) Simu- 
lating species loss following perturbation: assessing the effects on process rates. Proc R Soc Lond B 269:1047-1052

Kangas P, Autio H, Hällfors G, Luther H, Niemi Å, Salemaa H (1982) A general model of the decline of Fucus vesiculosus at Tvärminne, south coast of Finland in 1977-1981. Acta Bot Fenn 118:1-27

Kenworthy WJ, Reid JP (2003) Can the calcifying macroalga Halimeda opuntia increase $\mathrm{CO}_{2}$ availability and enhance the growth of Thalassia testudinum? Gulf Mex Sci 21:101-102

Kinzig AP, Pacala SW, Tilman D (eds) (2002) The functional consequences of biodiversity. Empirical progress and theoretical expectations. Princeton University Press, Princeton, NJ

Klumpp DW, Howard RK, Pollard DA (1989) Trophodynamics and nutritional ecology of seagrass communities. In: Larkum AWD, McComb AJ, Shepherd SA (eds) Biology of seagrasses. Elsevier, Amsterdam, p 394-457

Kohn AJ (1967) Environmental complexity and species diversity in the gastropod genus Conus on Indo-West Pacific reef platforms. Am Nat 101:251-259

Kotler BP, Brown JS (1988) Environmental heterogeneity and the coexistence of desert rodents. Annu Rev Ecol Syst 19: 281-307

Leibold MA (1989) Resource edibility and the effects of predators and productivity on the outcome of trophic interactions. Am Nat 134:922-949

Leibold MA (1996) A graphical model of keystone predators in food webs: trophic regulation of abundance, incidence, and diversity patterns in communities. Am Nat 147: $784-812$

Lemmens JWTJ, Clapin G, Lavery Pl, Cary J (1996) Filtering capacity of seagrass meadows and other habitats of Cockburn Sound, Western Australia. Mar Ecol Prog Ser 143: $187-200$

Levine JM, D'Antonio CM (1999) Elton revisited: a review of evidence linking diversity and invasibility. Oikos 87:15-26

Lewis FG III (1987) Crustacean epifauna of seagrass and macroalgae in Apalachee Bay, Florida, USA. Mar Biol 94: 219-229

Lipcius RN, Eggleston DB, Miller DL, Luhrs TC (1998) The habitat-survival function of Caribbean spiny lobster: an inverted size effect and non-linearity in mixed algal and seagrass habitats. Mar Freshw Res 49(8):807-816

Lohrer AM, Thrush SF, Gibbs MM (2004) Bioturbators enhance ecosystem function through complex biogeochemical interactions. Nature 431:1092-1095

Loreau M (2004) Does functional redundancy exist? Oikos 104:606-610

Loreau M, Naeem S, Inchausti P, Bengtsson J and 8 others (2001) Biodiversity and ecosystem functioning: current knowledge and future challenges. Science 294:804-808

Loreau M, Downing A, Emmerson M, Gonzalez A and 5 others (2002a) A new look at the relationship between diversity and stability. In: Loreau M, Naeem S, Inchausti P (eds) Biodiversity and ecosystem functioning: synthesis and perspectives. Oxford University Press, Oxford, p 79-91

Loreau M, Naeem S, Inchausti P (eds) (2002b) Biodiversity and ecosystem functioning. Oxford University Press, Oxford

Loreau M, Mouquet N, Gonzalez A (2003) Biodiversity as spatial insurance in heterogeneous landscapes. Proc Natl Acad Sci USA 100:12765-12770

Lotze HK, Milewski I (2004) Two centuries of multiple human impacts and successive changes in a North Atlantic food web. Ecol Appl 14:5:1428-1447

Lundberg J, Moberg F (2002) Mobile link organisms and eco- system functioning: implications for ecosystem resilience and management. Ecosystems 6:87-98

Meyer JL, Schultz ET, Helfman GS (1983) Fish schools: an asset to corals. Science 220:1047-1049

Micheli F, Halpern BS (2005) Low functional redundancy in coastal marine assemblages. Ecol Lett 8:391-400

Micheli F, Peterson CH (1999) Estuarine vegetated habitats as corridors for predator movements. Conserv Biol 13: 869-881

Montoya JM, Rodriguez MA, Hawkins BA (2003) Food web complexity and higher-level ecosystems services. Ecol Lett 6:587-593

Mulder CPH, Koricheva J, Huss-Danell K, Högberg P, Joshi J (1999) Insects affect relationships between plant species richness and ecosystem processes. Ecol Lett 2:237-246

Mumby PJ, Edwards AJ, Arias-Gonzalez JE, Lindeman KC and 8 others (2004) Mangroves enhance the biomass of coral reef fish communities in the Caribbean. Science 427:533-536

Myers RA, Worm B (2003) Rapid worldwide depletion of predatory fish communities. Nature 423:280-283

Naeem S (1998) Species redundancy and ecosystem reliability. Conserv Biol 12:39-45

Naeem S (2002) Ecosystem consequences of biodiversity loss: the evolution of a paradigm. Ecology 83:1537-1552

Naeem S (2006) Expanding scales in biodiversity-based research: challenges and solutions for marine systems. Mar Ecol Prog Ser 311:273-283 (in this Theme Section)

Naeem S, Li S (1998) Consumer species richness and autotrophic biomass. Ecology 79:2603-2615

Naeem S, Wright JP (2003) Disentangling biodiversity effects on ecosystem functioning: deriving solutions to a seemingly insurmountable problem. Ecol Lett 6:567-579

Naeem S, Hahn DR, Schuurman G (2000) Producer-decomposer co-dependency influences biodiversity effects. Nature 403: 762-764

Norberg J, Swaney DP, Dushoff J, Lin J, Casagrandi R, Levin SA (2001) Phenotypic diversity and ecosystem functioning in changing environments: a theoretical framework. Proc Natl Acad Sci USA 98:11376-11381

Orth RJ (1992) A perspective on plant-animal interactions in seagrasses: physical and biological determinants influencing plant and animal abundance. In: John DM, Hawkins SJ, Price JH (eds) Plant-animal interactions in the marine benthos. Clarendon Press, Oxford, p 147-164

Orth RJ, Heck KL Jr, van Montfrans J (1984) Faunal communities in seagrass beds: a review of the influence of plant structure and prey characteristics on predator-prey relationships. Estuaries 7:339-350

Ostfeld RS, LoGiudice K (2003) Community disassembly, biodiversity loss, and the erosion of an ecosystem service. Ecology 84:1421-1427

Pace ML, Cole JJ, Carpenter SR, Kitchell JF (1999) Trophic cascades revealed in diverse ecosystems. Trends Ecol Evol 14:483-488

Palumbi SR (2001) The ecology of marine protected areas. In: Bertness MD, Gaines SD, Hay ME (eds) Marine community ecology. Sinauer Associates, Sunderland, MA, p 509-530

Pandolfi JM, Bradbury RH, Sala E, Hughes TP and 8 others (2003) Global trajectories of the long-term decline of coral reef ecosystems. Science 301:955-958

Parker JD, Duffy JE, Orth RJ (2001) Plant species diversity and composition: experimental effects on marine epifaunal assemblages. Mar Ecol Prog Ser 224:55-67

Pauly D, Christensen V, Dalsgaard J, Froese R, Torres F Jr (1998) Fishing down marine food webs. Science 279: 
$860-863$

Pfisterer AB, Schmid B (2002) Diversity-dependent production can decrease the stability of ecosystem functioning. Nature 416:84-86

Polis GA, Anderson WB, Holt RD (1997) Toward an integration of landscape and food-web ecology: the dynamics of spatially subsidized food webs. Annu Rev Ecol Syst 28: 289-316

Polis GA, Power ME, Huxel GR (eds) (2004) Food webs at the landscape level. University of Chicago Press, Chicago

Posey MH (1988) Community changes associated with the spread of an introduced seagrass, Zostera japonica. Ecology 69:974-983

Powell GVN, Fourqurean JW, Kenworthy WJ, Aieman JC (1991) Bird colonies cause seagrass enrichment in a subtropical estuary: observational and experimental evidence. Estuar Coast Shelf Sci 32:6:567-579

Power ME, Tilman, Estes JA, Menge BA and 6 others (1996) Challenges in the quest for keystones. BioScience 46: 609-620

Raffaelli D, Raven JA, Poole LJ (1998) Ecological impacts of green macroalgal blooms. Oceanogr Mar Biol Annu Rev $36: 97-125$

Reusch TBH (1998) Native predators contribute to invasion resistance to the non-indigenous bivalve Musculista senhousia in southern California, USA. Mar Ecol Prog Ser 170:159-168

Reusch TBH, Hughes AR (2006) The emerging role of genetic diversity for ecosystem functioning: estuarine macrophytes as model systems. Estuaries (in press)

Reusch TBH, Williams SL (1998) Variable responses of native eelgrass Zostera marina to a non-indigenous bivalve Musculista senhousia. Oecologia 113:428-441

Reusch TBH, Ehlers A, Hämmerli A, Worm B (2005) Ecosystem recovery after climatic extremes enhanced by genotypic diversity. Proc Natl Acad Sci USA 102:2826-2831

Rosenzweig ML (1971) Paradox of enrichment: destabilization of exploitation ecosystems in ecological time. Science 171: 385-387

Sala OE, Chapin FS, Armesto JJ, Berlow E and 15 others (2000) Global biodiversity scenarios for the year 2100 . Science 287:1770-1774

Sax DF, Gaines SD (2003) Species diversity: from global decreases to local increases. Trends Ecol Evol 18:561-566

Sax DF, Stachowicz JJ, Gaines SD (eds) (2005) Species invasions: insights into ecology, evolution, and biogeography. Sinauer, Sunderland, MA

Schmitz OJ, Hambaeck PA, Beckerman AP (2000) Trophic cascades in terrestrial systems: a review of the effects of carnivore removals on plants. Am Nat 155:141-153

Schwartz MW, Brigham CA, Hoeksema JD, Lyons KG, Mills $\mathrm{MH}$, van Mantgem PJ (2000) Linking biodiversity to ecosystem function: implications for conservation ecology. Oecologia 122:297-305

Short FT, Wyllie-Echeverria S (1996) Natural and humaninduced disturbances of seagrasses. Environ Conserv 23: $17-27$

Shurin JB, Borer ET, Seabloom EW, Anderson K, Blanchette CA, Broitman Cooper SD, Halpern BS (2002) A crossecosystem comparison of the strength of trophic cascades. Ecol Lett 5:785-791

Siemann E, Tilman D, Haarstad J, Ritchie M (1998) Experimental tests of the dependence of arthropod diversity on plant diversity. Am Nat 152:738-750

Silliman BR, Bertness MD (2002) A trophic cascade regulates salt marsh primary production. Proc Natl Acad Sci USA 99: 10500-10505
Simberloff D, Parker IM, Windle PN (2005) Introduced species policy, management, and future research needs. Front Ecol Environ 3:12-20

Solan M, Cardinale BJ, Downing AL, Engelhardt KAM, Ruesink JL, Srivastava DS (2004) Extinction and ecosystem function in the marine benthos. Science 306: $1177-1180$

Srivastava DS, Vellend M (2005) Biodiversity-ecosystem function research: Is it relevant to conservation? Annu Rev Ecol Evol Syst 36:267-294

Stachowicz JJ, Tilman D (2005) Species invasions and the relationships between species diversity, community saturation, and ecosystem functioning. In: Sax DF, Stachowicz JJ, Gaines SD (eds) Species invasions: insights into ecology, evolution, and biogeography. Sinauer, Sunderland, MA, p 41-64

Stachowicz JJ, Whitlatch RB, Osman RW (1999) Species diversity and invasion resistance in a marine ecosystem. Science 286:1577-1579

Stachowicz JJ, Fried H, Osman RW, Whitlatch RB (2002) Biodiversity, invasion resistance and marine ecosystem function: reconciling pattern and process. Ecology 83: $2575-2590$

Stoner AW, Lewis FG III (1985) The influence of quantitative and qualitative aspects of habitat complexity in tropical seagrass meadows. J Exp Mar Biol Ecol 94:19-40

Strong DR (1992) Are trophic cascades all wet? Differentiation and donor control in speciose ecosystems. Ecology 73: $747-754$

Suchanek TH, Williams SL, Ogden JC, Hubbard DK, Gill IP (1985) Utilization of shallow-water seagrass detritus by Caribbean deep-sea macrofauna: Del ${ }^{13} \mathrm{C}$ evidence. DeepSea Res 32:201-214

Tegner MJ, Dayton PK (1987) El Niño effects on southern California kelp forest communities. Adv Ecol Res 17: 243-279

Terborgh J, Estes JA, Paquet P, Ralls K, Boyd-Heger D, Miller BJ, Noss RF (1999) The role of top carnivores in regulating terrestrial ecosystems. In: Soulé ME, Terborgh J (eds) Continental conservation. Island Press, Washington, DC

Thébault E, Loreau M (2003) Food-web constraints on biodiversity-ecosystem functioning relationships. Proc Natl Acad Sci USA 100:14949-14954

Thrush SF, Dayton PK (2002) Disturbance to marine benthic habitats by trawling and dredging: implications for marine biodiversity. Annu Rev Ecol Syst 33:449-473

Tilman D (1999) The ecological consequences of changes in biodiversity: a search for general principles. J Ecol 80: 1455-1474

Valentine JF, Duffy JE (2005) The central role of grazing in seagrass ecosystems. In: Larkum AWD, Orth RJ, Duarte CM (eds) Seagrasses: biology, ecology, and conservation. Springer, New York

Valiela I, McClelland J, Hauxwell J, Behr PJ, Hersh D, Foreman K (1997) Macroalgal blooms in shallow estuaries: controls and ecophysiological and ecosystem consequences. Limnol Oceanogr 42:1105-1118

Van Elven BR, Lavery PS, Kendrick GA (2004) Reefs as contributors to diversity of epiphytic macroalgae assemblages in seagrass meadows. Mar Ecol Prog Ser 276:71-83

Virnstein RW, Howard RK (1987a) Motile epifauna of marine macrophytes in the Indian River Lagoon, Florida. I. Comparisons among three species of seagrasses from adjacent beds. Bull Mar Sci 41:1-12

Virnstein RW, Howard RK (1987b) Motile epifauna of marine macrophytes in the Indian River Lagoon, Florida. II. Com- 
parisons between drift algae and three species of seagrasses. Bull Mar Sci 41:13-26

Waldbusser GG, Marinelli RL, Whitlatch RB, Visscher PT (2004) The effects of infaunal biodiversity on biogeochemistry of coastal marine sediments. Limnol Oceanogr 49: 1482-1492

Wardle DA, Huston MA, Grime JP, Berendse F, Garnier E, Lauenroth WK, Setälä H, Wilson SD (2000) biodiversity and ecosystem function: an issue in ecology. Bull Ecol Soc Am Jul 2000:235-239

Watling L, Norse EA (1998) Disturbance of the seabed by mobile fishing gear: a comparison to forest clearcutting. Conserv Biol 12:1180-1197

Whitham TG, Young WP, Martinsen GD, Gehring CA and 8 others (2003) Community and ecosystem genetics: a consequence of the extended phenotype. Ecology 84:559-573

Widdicombe S, Austen MC, Kendall MA, Olsgard F, Schaanning MT, Dashfield SL, Needham HR (2004) Importance of bioturbators for biodiversity maintenance: indirect effects of fishing disturbance. Mar Ecol Prog Ser 275:1-10

Wigand C, Stevenson JC, Cornwell JC (1997) Effects of different submersed macrophytes on sediment biogeochemistry. Aquat Bot 56:233-244

Williams SL (1990) Experimental studies of Caribbean seagrass development. Ecol Monogr 60:449-469

Williams SL (2001) Reduced genetic diversity in eelgrass transplantations affects both population growth and individual fitness. Ecol Appl 11:1472-1488

Editorial responsibility: Martin Solan (Guest Editor), Newburgh, UK
Williams SL, Heck KL Jr (2001) Seagrass community ecology. In: Bertness MD, Hay ME, Gaines SD (eds) Marine community ecology. Sinauer Associates, Sunderland, MA, p 120-150

Williams SL, Ruckelshaus MH (1993) Effects of nitrogen availability and herbivory on eelgrass (Zostera marina) and epiphytes. Ecology 74:904-918

Wing SR, Wing ES (2001) Prehistoric fisheries in the Caribbean. Coral Reefs 20:1-8

Witman JD, Ellis JC, Anderson WB (2004) The influence of physical processes, organisms, and permeability on crossecosystem fluxes. In: Polis GA, Power ME, Huxel GR (eds) Food webs at the landscape level. University of Chicago Press, Chicago, p 335-358

Worm B, Duffy JE (2003) Biodiversity, productivity, and stability in real food webs. Trends Ecol Evol 18:628-632

Worm B, Myers RA (2003) A meta-analysis of cod-shrimp interactions reveals top-down control in oceanic food webs. Ecology 84:162-173

Worm B, Sandow M, Oschlies A, Lotze HK, Myers RA (2005) Global patterns of predator diversity in the open oceans. Science 309:1365-1369

Yachi S, Loreau M (1999) Biodiversity and ecosystem productivity in a fluctuating environment: the insurance hypothesis. Proc Natl Acad Sci USA 96:1463-1468

Zavaleta ES, Hulvey K (2004) Realistic species losses disproportionately reduce grassland resistance to biological invaders. Science 306:1175-1177

Submitted: February 10, 2005; Accepted: November 10, 2005 Proofs received from author(s): March 9, 2006 